\title{
SUPPORT EFFECT ON CONVERSION OF QUINOLINE OVER ReS 2 CATALYST
}

\author{
R. BASSI ${ }^{a}$, M. VILLARROEL ${ }^{b}$, F. J. GIL-LLAMBIAS ${ }^{b}$, P. BAEZA ${ }^{a}$, J. L. GARCÍA-FIERRO', N. MARTÍNEZ \\ P. OLIVERA ${ }^{d}$, K. LEIVA ${ }^{d}$, N. ESCALONA ${ }^{e, f, g_{*}}$ \\ ${ }^{a}$ Pontificia Universidad Católica de Valparaíso, Facultad de Ciencias, Instituto de Química, Casilla 4059, Valparaíso, Chile. \\ ${ }^{b}$ Universidad de Santiago de Chile, Casilla 40, Correo 33, Santiago, Chile \\ 'Instituto de Catálisis y Petroquímica, CSIC, Cantoblanco, 28049 Madrid, Spain. \\ ${ }^{d}$ Universidad de Concepción, Facultad de Ciencias Químicas, Casilla 160C, Concepción, Chile. \\ e Departamento de Ingeniería Química y Bioprocesos, Escuela de Ingeniería, Pontificia Universidad Católica de Chile, \\ Avenida Vicuña Mackenna 4860, Macul, Santiago, Chile. \\ ${ }^{f}$ Departamento de Química Física, Facultad de Químicas, Pontificia Universidad Católica de Chile. \\ ${ }^{g}$ Centro de Investigación en Nanotecnología y Materiales Avanzados (CIEN-UC), Pontificia Universidad Católica de Chile, Santiago, Chile.
}

\begin{abstract}
The conversion of quinoline over $\mathrm{ReS}_{2}$ supported on $\gamma-\mathrm{Al}_{2} \mathrm{O}_{3}, \mathrm{SiO}_{2}, \mathrm{ZrO}_{2}$ and $\mathrm{TiO}_{2}$ catalysts in a batch reactor at $300{ }^{\circ} \mathrm{C}$ and $5 \mathrm{MPa}$ of hydrogen pressure was studied. The catalysts were prepared by wet impregnation with a loading of 1.5 atoms of Re per $\mathrm{nm}^{2}$ of support. The catalysts were characterized by $\mathrm{N}_{2}$ adsorption, $\mathrm{X}$-ray photoelectron spectroscopy (XPS) and X-ray powder diffraction (XRD). The $\operatorname{Re}(\mathrm{x}) / \mathrm{supports}$ catalysts displayed high activities for the conversion of quinoline, although negligible formation of $\mathrm{N}$-free compounds (hydrodenitrogenation) were observed. The intrinsic activities of $\mathrm{ReS}_{2}$ were modified by the support decreased in the order: $\mathrm{Re} / \mathrm{TiO}_{2}>\mathrm{Re} / \mathrm{ZrO}_{2}>\mathrm{Re} / \mathrm{SiO}_{2}>\mathrm{Re} / \gamma-\mathrm{Al}_{2} \mathrm{O}_{3}$. The highest activity displayed by the $\mathrm{Re} / \mathrm{TiO}_{2}$ catalyst was correlated with the Re dispersion and formation of $\mathrm{ReS}_{2}$ species. Meanwhile, the lower conversion of quinoline over the $\mathrm{Re} / \mathrm{ZrO}{ }_{2}, \mathrm{Re} / \mathrm{SiO}_{2}$ and $\mathrm{Re} / \gamma$ - $\mathrm{Al}_{2} \mathrm{O}_{3}$ catalysts was related to the combined effect of the textural properties of catalysts and the formation of $\operatorname{ReS}_{(2-x)}$ species on the supports.
\end{abstract}

Keywords: Hydrodenitrogenation, $\mathrm{ReS}_{2}$, quinoline, supports.

\section{INTRODUCTION}

Recently, the quality of crude oil has declined due to the contents of heavier nitrogen and sulfur organic compounds which hinder the hydrotreating processes (HT), particularly hydrodesulfurization (HDS) and hydrodenitrogenation (HDN). Moreover, stringent environmental regulations have forced the oil industry to reduce the nitrogen and sulfur levels present in fuels. In order to meet the required standards, it is essential to find catalysts that are more active than the classical $\mathrm{HT} \mathrm{Ni}(\mathrm{Co})-\mathrm{Mo} / \mathrm{Al}_{2} \mathrm{O}_{3}$ catalysts. In this context, several researches have been carried out in order to either improve the activity of classical sulfides catalysts or find alternative catalysts $[1,2,3]$.

Liu et al. [1] studied the effects of the addition of fluorine and phosphorus on $\mathrm{Ni}-\mathrm{Mo} / \mathrm{Al}_{2} \mathrm{O}_{3}$ catalysts in the $\mathrm{HDN}$ of quinoline. They found that fluorine and phosphorus promote the activity of $\mathrm{Ni}-\mathrm{Mo} / \mathrm{Al}_{2} \mathrm{O}_{3}$ catalysts, attributing this behavior to the promotion of weak and moderate acid sites, as well as the enhancement of Mo dispersion.

Deepa et al. [4] investigated the effect of supports on the HDN of quinoline and 1,2,3,4-tetrahydroquinoline (THQ1) over Ni-Mo catalysts. The highest quinoline conversion was displayed by Ni-Mo supported on a B-zeolite dealuminated blend with $\mathrm{Al}_{2} \mathrm{O}_{3}\left(\mathrm{Al}_{2} \mathrm{O}_{3}-\mathrm{DAl} \mathrm{BEA}-\mathrm{Al}\right)$, followed by $\mathrm{Ni}-\mathrm{Mo} /$ $\mathrm{Al}_{2} \mathrm{O}_{3}$ catalyst. On the other hand, the highest THQ1 conversion was presented by $\mathrm{Ni}-\mathrm{Mo} / \mathrm{Al}_{2} \mathrm{O}_{3}$ (DAl BEA-AL), followed by $\mathrm{Ni}-\mathrm{Mo} / \mathrm{AlMCM}-41$ catalyst. The trend obtained was attributed mainly to differences in the acid strength of supports used.

Yang and Satterfield [5] studied the effect of hydrogen sulfide on the HDN of quinoline using $\mathrm{NiMo} / \mathrm{Al}_{2} \mathrm{O}_{3}$ catalyst. They found that the hydrogen sulfide inhibits hydrogenation and dehydrogenation reactions but markedly accelerates hydrogenolysis reactions.

Moreau et al. [6] studied HDN of quinoline using mechanical mixtures of industrial pre-sulfided alumina-supported Ni-Mo and Co-Mo catalysts. They found a substantial promotion effect, due mainly to the better hydrogenolysis properties of the catalysts mixtures. The authors indicated that this effect could be due to a novel active phase or due to a bifunctional mechanism.

The reactivity of non-classical catalysts has also been studied for HDN and HDS reactions. Ni-rich bimetallic phosphides incorporating different metals displayed high activity in the simultaneous HDN of quinoline and HDS of dibenzothiophene [2]. However, the HDS conversion and product selectivities were dependent on the adsorption of $\mathrm{N}$-containing compounds on the active sites of catalysts $[7,8]$. These results reiterated that the removal of nitrogen from heterocyclic compounds is a more difficult process than the removal of sulfur, and generally leads to deactivation of catalysts.
Chouzier et al. [9] studied (Ni, Co)-Mo binary and ternary nitrides in the HDN of quinoline. They found that the active phase for monometallic nitrides was $\mathrm{MoS}_{2}$ formed on the surface of nitride particles. This was confirmed by the poor activity of the nitride in the absence of sulfur. The authors reported synergism for these bimetallic nitride systems, and indicated that the active sites are probably some ensembles of metallic atoms on the surface of mixed phases $\mathrm{Co}_{3} \mathrm{Mo}_{3} \mathrm{~N}$ and $\mathrm{Ni}_{2} \mathrm{Mo}_{3} \mathrm{~N}$.

On the other hand, Eijsbouts et al. [10] studied the reactivities of first-, second-, and third-row transition metal sulfide (TMS) supported on activated carbon in the HDN of quinoline. They found that the first-row transition metal sulfides displayed low quinoline conversion to hydrocarbons. On the other hand, the second- and third-row TMS formed a volcanic curve with maxima at $\mathrm{Rh} / \mathrm{C}$ and $\mathrm{Ir} / \mathrm{C}$ catalysts, respectively. On this curve, $\mathrm{Re} / \mathrm{C}$ presented intermediate activity but with a high selectivity for propylbenzene. The $\mathrm{ReS}_{2}$ catalyst has been rarely studied for HDN reactions although a $\mathrm{ReS}_{2} / \mathrm{Al}_{2} \mathrm{O}_{3}$ catalyst exhibited a higher activity ( 1.6 times) than the $\mathrm{Ni}-\mathrm{Mo} / \mathrm{Al}_{2} \mathrm{O}_{3}$ catalyst in the HDS of thiophene [11].

Escalona et al. [12] studied the simultaneous HDS and HDN reaction over $\mathrm{ReS}_{2} / \mathrm{Al}_{2} \mathrm{O}_{3}$ catalyst. They found that the HDN/HDS selectivity increases with increasing Re loading, which was attributed to changes in the acid sites of the catalysts. A similar behavior was also observed in the simultaneous HDS and HDN over $\mathrm{ReS}_{2} / \mathrm{C}$ catalysts [13].

On the other hand, Laurenti et al. [14] studied the HDS of thiophene over $\mathrm{ReS}_{2}$ supported on $\mathrm{Al}_{2} \mathrm{O}_{3}, \mathrm{ZrO}_{2}$ and $\mathrm{TiO}_{2}$. They found that the $\mathrm{ReS}_{2} / \mathrm{ZrO}_{2}$ catalyst displayed the highest activity followed by $\mathrm{ReS}_{2} / \mathrm{Al}_{2} \mathrm{O}_{3}$ and $\mathrm{ReS}_{2} / \mathrm{TiO}_{2}$ catalysts, and that catalytic activity was strongly dependent on the sulfidation mixture used, similar to previous findings by Escalona et al. [11].

It is well known that the activity of transition metal sulfides strongly depends on the type of support used. The support can influence the interaction between its surface and the active phase, the dispersion, degree of sulfurization, stability, and structure of the active phase, etc. [15, 16, 17, 18]. Therefore, the aim of this work is to study the effect of support $\left(\mathrm{TiO}_{2}, \mathrm{Al}_{2} \mathrm{O}_{3}, \mathrm{SiO}_{2}\right.$ and $\left.\mathrm{ZrO}_{2}\right)$ on conversion of quinoline using Re sulfide as active phase. The preparation of Re sulfide catalysts was carried out with $\mathrm{N}_{2} / \mathrm{H}_{2} \mathrm{~S}$ mixture, following a procedure previously reported by Escalona et al. [14].

\section{2.- EXPERIMENTAL}

2.1 Catalyst preparation

The supported rhenium-based catalysts were prepared by incipient wetness impregnation of an aqueous solution of $\mathrm{NH}_{4} \mathrm{ReO}_{4}$ (Aldrich, 99\%) on 
$\mathrm{SiO}_{2}$ (BASF D10-11), $\gamma-\mathrm{Al}_{2} \mathrm{O}_{3}$ (BASF D10-10), $\mathrm{TiO}_{2}$ (p25 Degussa) and $\mathrm{ZrO}_{2}$ The $\mathrm{ZrO}$, support was obtained by direct calcination of a commercial hydrous zirconium $\mathrm{Zr}(\mathrm{OH})_{4}$ (MEL Chemicals) at $573 \mathrm{~K}$ for $3 \mathrm{~h}$ in a muffle furnace. The catalysts were prepared with a loading 1.5 atoms of Re per $\mathrm{nm}^{2}$ of support. The impregnated catalysts were left for maturation at room temperature for 24 $\mathrm{h}$, dried at $393 \mathrm{~K}$ for $12 \mathrm{~h}$, and then calcined at $573 \mathrm{~K}$ for $0.5 \mathrm{~h}$. The calcined samples were pre-sulfided at $673 \mathrm{~K}$ for $4 \mathrm{~h}$ under a flow of $10 \% \mathrm{H}_{2} \mathrm{~S} / \mathrm{N}_{2}$ mixture. The Re content was determined by ICP-OES using the Re emission line of $221.426 \mathrm{~nm}$

\subsection{Characterization of the Catalysts}

The BET surface area $\left(\mathrm{S}_{\mathrm{BET}}\right)$ and total pore volume $\left(\mathrm{V}_{\mathrm{p}}\right)$ of the support and the $\mathrm{ReOx} /$ support catalysts were determined from nitrogen isotherms at $77 \mathrm{~K}$ using a Micromeritics-TriStar II 3020 instrument.

X-ray powder diffraction (XRD) patterns were obtained by means of a Rigaku diffractometer equipped with a nickel-filtered $\mathrm{CuK} \alpha_{1}$ radiation $(1=$ $\left.1.5418^{\circ} \mathrm{A}\right)$.

XPS measurements were performed using a VG Escalab 200R electron spectrometer equipped with a hemispherical electron analyzer and a $\mathrm{Mg} \mathrm{K \alpha}$ $(1253.6 \mathrm{eV})$ excitation source. Energy corrections were performed using the line of each support as internal reference. The samples were treated as previously stated, cooled to room temperature, flushed with $\mathrm{N}_{2}$, stored in flasks containing $n$-heptane, and transferred into the pretreatment chamber of the spectrometer. The XPS analyses of these samples were categorized as prereaction. After the HDN reaction, the spent catalyst was transferred into flasks containing n-dodecane, and analyzed by XPS. The intensity of the peaks was estimated by calculating the integral of each peak after subtracting an S-shaped background and fitting the experimental curve to a combination of Gaussian/ Lorentzian lines.

\subsection{Catalytic tests}

The HDN of quinoline was carried out in an autoclave reactor operating in batch mode. The liquid reactant feed, consisting of quinoline $\left(0.232 \mathrm{~mol} \mathrm{~L}^{-1}\right)$ in decahydronaphthalene (decaline) $(80 \mathrm{~mL})$ with hexadecane $\left(0.0341 \mathrm{~mol} \mathrm{~L}^{-1}\right)$ as internal standard, was introduced into the reactor. Then, approximately 0.200 $\mathrm{g}$ of the selected catalyst was added. As previously indicated, the $\operatorname{ReS}_{2}(\mathrm{x}) /$ supports were prepared from the ex situ sulfidation and quickly transferred to the reactor to prevent oxidation. The system was closed, and $\mathrm{N}_{2}$ was bubbled through the solution for $20 \mathrm{~min}$ with a flow of $100 \mathrm{~mL} \mathrm{~min}^{-1}$ to purge any air in the system. Still under $\mathrm{N}_{2}$ atmosphere, the reactor was heated to the reaction temperature of $573 \mathrm{~K}$ with stirring. The reaction timer was initiated when the reaction temperature was reached and the pressure was adjusted to $5 \mathrm{MPa}$ by $\mathrm{H}_{2}$. The pressure was kept constant during the course of the experiment. Condensed samples were taken periodically during the reaction and quantified by a gas chromatograph (Perkin-Elmer - Clarus 400) equipped with a Flame Ionization Detector (FID) and a CP-Sil 5 column (Agilent, $30 \mathrm{~m} \times 0.53 \mathrm{~mm} \times$ $1.0 \mu \mathrm{m}$ film thickness).

The specific rate for the total conversion of quinoline was deduced from the initial slope of conversion as a function of time plot according to the following equation:

$$
r_{s}=\frac{[b \times n]}{m}
$$

where $r_{s}$ is the specific rate $\left(\mathrm{mol} \mathrm{g}^{-1} \mathrm{~s}^{-1}\right), \mathrm{b}$ represents the initial slope of the conversion vs. time plot (dimensionless), $\mathrm{n}$ is the initial moles of quinoline $(\mathrm{mol})$, and $\mathrm{m}$ is the mass of catalyst $(\mathrm{g})$. The intrinsic rate was calculated from the specific rate according to the following equation:

$$
r_{i}=\frac{r_{s}}{n \operatorname{Re}} * N_{a v} \text { Eq. (2) }
$$

where $r_{i}$ is

the intrinsic rate (represent the molecules of quinoline transformed per Re atom and second; and it is expressed as molec. Re at ${ }^{-1} \mathrm{~s}^{-1}$ ), and $\mathrm{r}_{\mathrm{s}}$ is the specific rate (expressed as moles of quinoline transformed per gram of catalyst per second [mol. $\mathrm{g}_{\text {cat }}^{-1} \mathrm{~s}^{-1}$ ), nRe represents the number of Re atoms per gram of catalyst, and $\mathrm{N}_{\mathrm{av}}$ is the Avogadro number.

The selectivities (\%) were determined at $40 \%$ of quinoline conversion, according to Eq. (2):

$$
S \%=\frac{X_{i}}{X_{T}} \times 100
$$

where $\mathrm{X}_{\mathrm{i}}$ is the percentage of product formation $i$, and $X_{T}$ is the quinoline conversion.

\section{RESULTS AND DISCUSSION}

3.1 Characterization of catalysts

Figure 1 shows the $\mathrm{N}_{2}$ adsorption-desorption isotherms of the supports. According to IUPAC classifications, all the isotherms belong to type IV which is typical of mesoporous materials [19]. Also, Fig. 1 shows that the $\gamma-\mathrm{Al}_{2} \mathrm{O}_{3}$ and $\mathrm{ZrO}$, supports displayed a hysteresis loop, closely resembling a type $\mathrm{H}_{3}$, due to capillary condensation which is typically associated to non-interconnected ink-bottle pores. Meanwhile, the $\mathrm{TiO}_{2}$ and $\mathrm{SiO}_{2}$ supports displayed a hysteresis loop resembling a type $\mathrm{H} 3$, suggestive of slit-shaped pores. The $\mathrm{N}_{2}$ adsorptiondesorption isotherms of the catalysts (not shown here) were similar to their respective supports. The textural properties from $\mathrm{N}_{2}$ adsorption-desorption isotherms of the supports and catalysts are summarized in Table 1 . The $\gamma$ - $\mathrm{Al}_{2} \mathrm{O}_{3}$ support possessed the highest surface area, followed by $\mathrm{SiO}_{2}, \mathrm{TiO}_{2}$ and $\mathrm{ZrO}_{2}^{2}$ supports. Also, there was a slight decrease in textural properties of the supports (surface area and the total, micropore and mesopore pore volumes) after Re impregnation, suggesting that pore mouth blockage was practically absent.

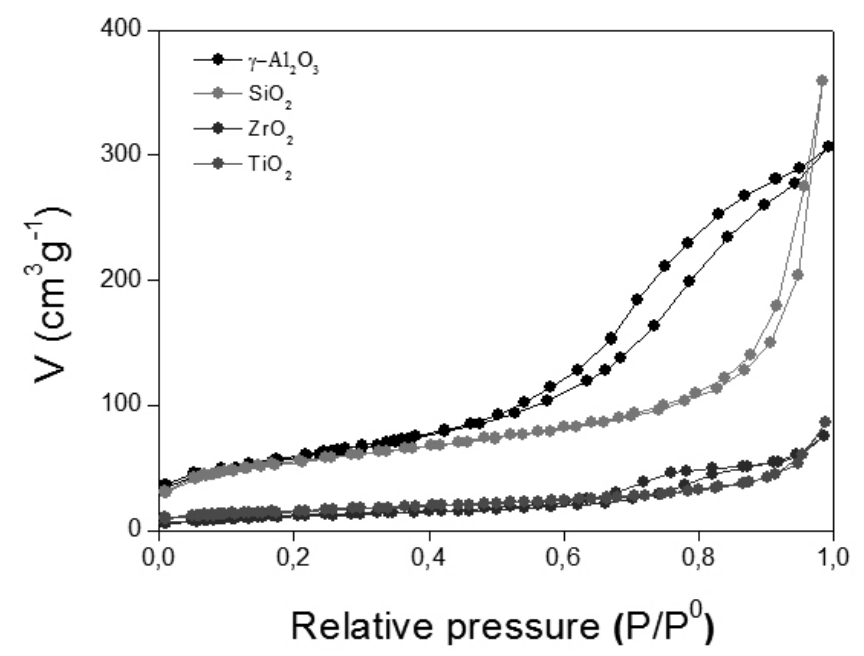

Figure 1: Nitrogen adsorption - desorption isotherms of supports.

Figure 2 shows the XRD patterns of the calcined Re/support catalysts. The patterns obtained were compared to JCPDS data files for phase identification ( $\mathrm{ReO}_{4}^{-}:$:010-0252, $\mathrm{ReO}_{3}: 041-0967, \mathrm{TiO}_{2}:$ : 01-086-1157; $\mathrm{SiO}_{2}$ : 01-087-0710, $\left.\mathrm{ZrO}_{2}: 037-1484, \mathrm{Al}_{2} \mathrm{O}_{3}: 010-0425\right)$. Figure $2 \mathrm{a}$ and $2 \mathrm{~b}$ shows the presence of $\mathrm{ReO}_{4}^{-}$(main peaks $2 \mathrm{q}=16.7 ; 25.4 ; 27.6 ; 30.4 ; 40.6 ; 41.3 ; 43.48 ; 47.2 ; 49.2$; $50.9 ; 52.2$ ) and $\mathrm{ReO}_{3}$ (main peaks $2 \mathrm{q}=34.8 ; 37.9 ; 59.0 ; 82.4 ; 85.5$ ) species over $\mathrm{SiO}_{2}$ support. Also, it can be observed in Figs. $2 \mathrm{a}$ and $2 \mathrm{~b}$ that the intensity of the $\mathrm{ReO}_{4}^{-}$peaks was higher than the intensity of the $\mathrm{ReO}_{3}$ peaks, suggesting that $\mathrm{ReO}_{4}^{-}$species is the main crystalline phase on this supports, in agreement with Escalona et al. [12]. On the contrary, Fig. 2c shows no detected diffraction peaks attributed to $\mathrm{ReO}_{4}^{-}$and $\mathrm{ReO}_{3}$ species for the $\mathrm{ZrO}_{2}$-supported catalysts, suggesting that either ReOx was highly dispersed on this support or that some of the $\mathrm{ZrO}_{2}$ peaks may have masked the ReOx peaks. Meanwhile, Fig. $2 \mathrm{~d}$ shows that $\mathrm{ReO}_{4}^{-}$species was detected on $\mathrm{TiO}_{2}$ support. Table 1 summarized the crystal size calculated by Scherrer equation. The $\mathrm{ReO}_{4}^{-}$crystallite size was similar on all supports, around $50 \mathrm{~nm}$. However, this result contradicts a previously reported study by Arnoldy et al. [20]; they found by XRD that the $\mathrm{ReOx}$ particles size supported on $\mathrm{Re}(2.5) / \mathrm{SiO}_{2}$ and $\mathrm{Re}(2.43) / \gamma-\mathrm{Al}_{2} \mathrm{O}_{3}$ catalysts was around $200 \mathrm{~nm}$. This difference in ReOx particles size can be attributed to the impregnation method used by Arnoldy et al. [20]. They used several pore volume impregnation steps to reach high Re content, suggesting that this procedure favor the formation of larger ReOx particles size. 
Table 1. Composition, textural properties and crystal size obtained from X-ray diffraction of $\operatorname{ReOx}(\mathrm{x}) /$ support catalysts.

\begin{tabular}{|c|c|c|c|c|c|c|c|}
\hline Samples & $\begin{array}{c}\operatorname{Re} \\
\text { Content (\%) }\end{array}$ & $\begin{array}{l}\text { Re surface density } \\
\quad\left(\text { atoms } \mathbf{n m}^{-2}\right)\end{array}$ & ${ }_{\left(\mathbf{m}^{2} \mathbf{g}^{-1}\right)}^{\mathbf{S}_{\mathrm{BET}}}$ & $\underset{\left(\mathrm{cm}^{3} \mathbf{g}^{-1}\right)}{{ }^{\mathrm{b}} \mathbf{V p}}$ & $\underset{\left(\mathrm{cm}^{3} \mathbf{g}^{-1}\right)}{{ }^{\mathrm{c}} \mathbf{V m}}$ & $\begin{array}{c}{ }^{\mathrm{d}} \mathbf{V o} \\
\left(\mathrm{cm}^{3} \mathrm{~g}^{-1}\right)\end{array}$ & $\stackrel{{ }^{e} \mathrm{ReO}_{4}^{-}}{\text {Crystal size (nm) }}$ \\
\hline$\gamma-\mathrm{Al}_{2} \mathrm{O}_{3}$ & --- & --- & 211 & 0.55 & 0.46 & 0.09 & --- \\
\hline $\operatorname{Re}(1.5) / \gamma-\mathrm{Al}_{2} \mathrm{O}_{3}$ & 9.8 & 1.5 & 202 & 0.35 & 0.25 & 0.09 & 50 \\
\hline $\mathrm{ZrO}_{2}$ & -- & --- & 41 & 0.09 & 0.07 & 0.02 & --- \\
\hline $\mathrm{Re}(1.5) / \mathrm{ZrO}_{2}$ & 2.1 & 1.5 & 40 & 0.07 & 0.05 & 0.02 & n.d. \\
\hline $\mathrm{SiO}_{2}$ & --- & --- & 187 & 0.31 & 0.22 & 0.09 & --- \\
\hline $\operatorname{Re}(1.5) / \mathrm{SiO}_{2}$ & 8.7 & 1.5 & 144 & 0.26 & 0.19 & 0.06 & 47 \\
\hline $\mathrm{TiO}_{2}$ & --- & --- & 54 & 0.09 & 0.06 & 0.03 & --- \\
\hline $\operatorname{Re}(1.5) / \mathrm{TiO}_{2}$ & 2.3 & 1.5 & 45 & 0.08 & 0.06 & 0.02 & $56^{*}$ \\
\hline
\end{tabular}

${ }^{a}$ Determined from BET equation.

${ }^{\mathrm{b}}$ Calculated from the amount adsorbed at a relative pressure of 0.96.

${ }^{c}$ Determined from Dubinin-Radushkevich (D-R) equation.

${ }^{\mathrm{d}}$ Difference between $\mathrm{V}_{\mathrm{p}}$ and $\mathrm{V}_{\mathrm{p}}$.

${ }^{e} \mathrm{ReO}_{4}^{-}$crystal size determined from Scherrer equation using $2 \mathrm{q}=25.4^{\circ}$

* $\mathrm{ReO}_{4}^{-}$crystal size was calculated using $2 \mathrm{q}=16.7^{\circ}$
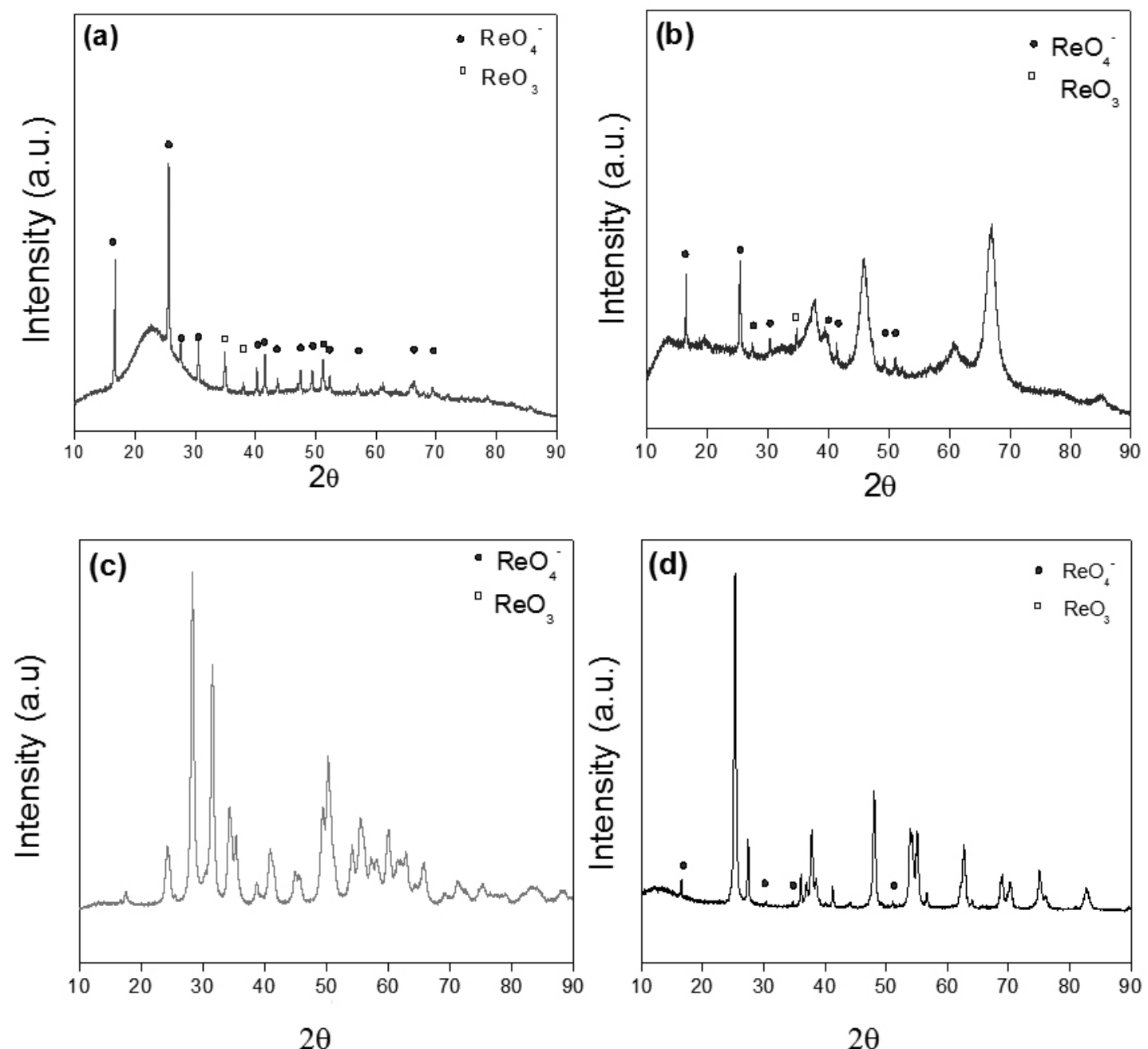

$2 \theta$

Figure 2: X-ray diffraction of a) $\mathrm{Re} / \mathrm{SiO}_{2}$, b) $\mathrm{Re} / \gamma-\mathrm{Al}_{2} \mathrm{O}_{3}$, c) $\mathrm{Re} / \mathrm{ZrO}_{2}$ and d) $\mathrm{Re} / \mathrm{TiO}_{2}$ catalysts. 
Table 2. XPS binding energies $(\mathrm{eV})$ and surface atomic ratios of sulfided catalysts.

\begin{tabular}{|c|c|c|c|c|}
\hline Catalysts & $\begin{array}{c}\text { M 2p } \\
\text { (Si, Al, Zr, Ti) (e.V.) }\end{array}$ & $\begin{array}{l}\operatorname{Re} 4 f_{7 / 2} \\
\text { (e.V.) }\end{array}$ & $\begin{array}{l}\text { S2p } \\
\text { (e.V.) }\end{array}$ & $\operatorname{Re} / M$ at \\
\hline $\operatorname{ReS}_{2}(1.5) / \mathrm{SiO}_{2}$ & 103.4 & 41.2 & 161.8 & 0.041 \\
\hline $\operatorname{ReS}_{2}(1.5) / \gamma-\mathrm{Al}_{2} \mathrm{O}_{3}$ & 74.5 & $\begin{array}{l}41.6(89) \\
43.3(11)\end{array}$ & 162.0 & 0.034 \\
\hline $\operatorname{ReS}_{2}(1.5) / \mathrm{ZrO}_{2}$ & 182.2 & $\begin{array}{l}41.6(88) \\
44.4(12)\end{array}$ & 162.0 & 0.028 \\
\hline $\operatorname{ReS}_{2}(1.5) / \mathrm{TiO}_{2}$ & 458.6 & 41.0 & 161.7 & 0.089 \\
\hline
\end{tabular}

Figure 3 shows the XPS spectra of Re/support catalysts with a surface density of 1.5 atoms of Re per $\mathrm{nm}^{2}$ of supports. Curve fitting of spectra in Figures $3 \mathrm{a}$ and $3 \mathrm{~d}$ revealed one doublet, each one containing the $\operatorname{Re} 4 \mathrm{f}_{712}$ and $\operatorname{Re} 4 f_{5 / 2}$ peaks, indicating the presence of one Re species. Meanwhile, curve fitting of the spectra in Fig. $3 \mathrm{~b}$ and $3 \mathrm{c}$ shows two partially overlapping doublets containing the $\operatorname{Re} 4 \mathrm{f}_{7 / 2}$ and $\operatorname{Re} 4 \mathrm{f}_{5 / 2}$ peaks, indicating the presence of two Re species. Table 2 summarizes the binding energies (BE) of the most intense Re $4 \mathrm{f}_{7 / 2}$ component of each doublet, its relative proportions (between parentheses) and surface atomic ratio for Re/supports catalysts. Table 3 shows that the Re $4 \mathrm{f}$ components of the most intense doublet remained constant in all the catalysts, at about $41.4 \mathrm{eV} \pm 0.3$, and corresponds closely to the values reported for $\operatorname{ReS}_{2}[12,21,22]$. A single peak for $\mathrm{S} 2 \mathrm{p}$ peaks at $162 \mathrm{eV} \pm 0.4$ indicates the presence of $\mathrm{S}^{2-}$ for all the sulfided catalysts. The $\mathrm{BE}$ of the $\mathrm{Re} 4 \mathrm{f}_{7 / 2}$ peaks of the less intense doublet displayed by $\mathrm{Re} / \gamma-\mathrm{Al}_{2} \mathrm{O}_{3}$ and $\mathrm{Re} / \mathrm{ZrO} \mathrm{C}_{2}$ catalysts was around $43.9 \mathrm{eV} \pm 0.3$, which can be assigned to Re oxysulfide species [12, 13, $21,22]$. These results indicate that Re sulfidation was slightly incomplete, and that the procedure used led to an estimated $90 \%$ sulfidation for $\gamma-\mathrm{Al}_{2} \mathrm{O}_{3}$ - and $\mathrm{ZrO}_{2}$-supported catalysts. This result suggests a strong interaction between $\mathrm{ReOx}$ species and these supports. On the other hand, the $\mathrm{Re} / \mathrm{TiO}$, and $\mathrm{Re} / \mathrm{SiO}_{2}$ catalysts displayed only a component of the $\operatorname{Re} 4 \mathrm{f}_{7 / 2}$ peak, indicating complete Re sulfidation.
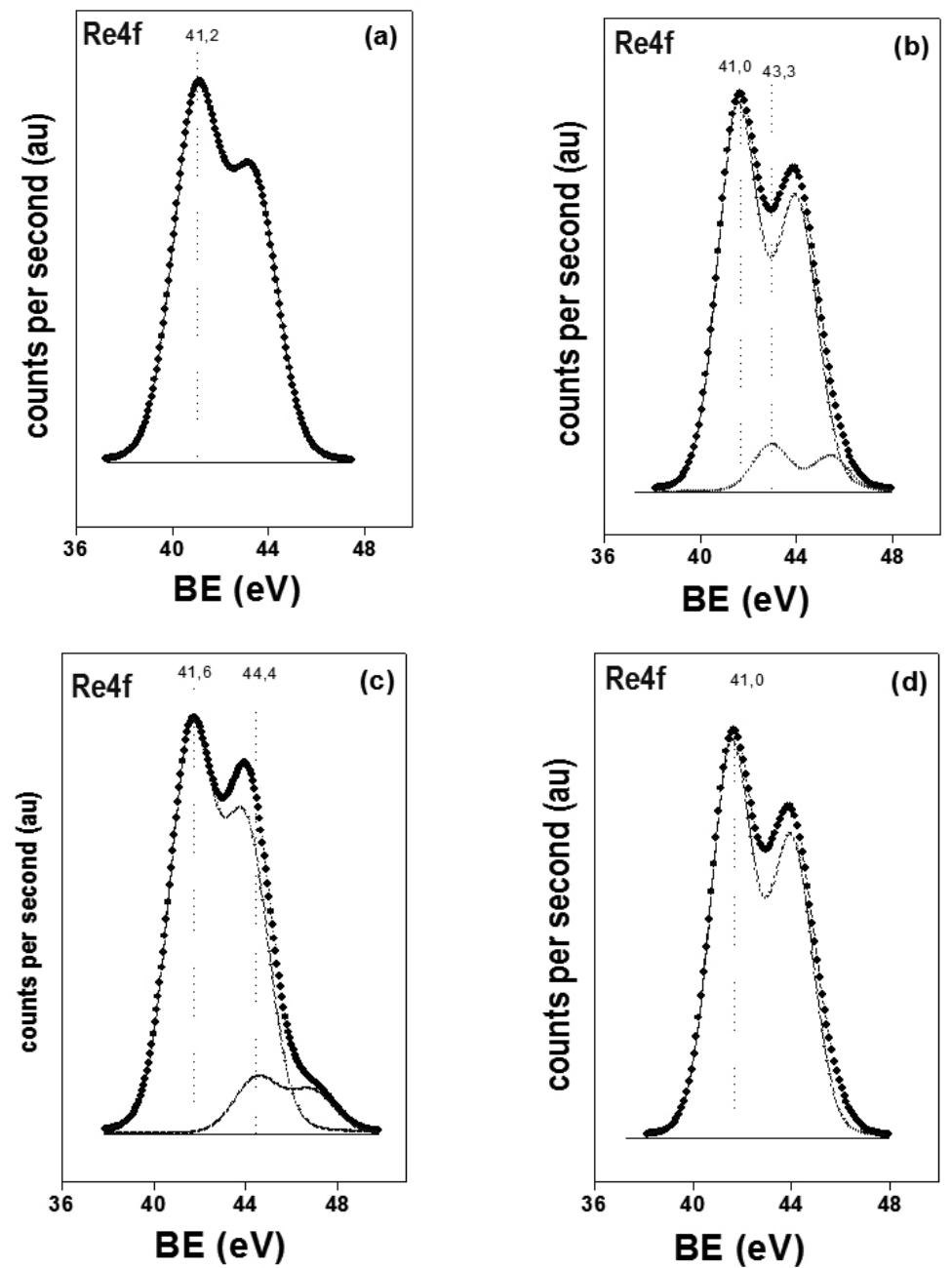

Figure 3: XPS of sulfides: a) $\mathrm{Re} / \mathrm{SiO}_{2}$, b) $\mathrm{Re} / \gamma-\mathrm{Al}_{2} \mathrm{O}_{3}$, c) $\mathrm{Re} / \mathrm{ZrO}$ and d) $\mathrm{Re} / \mathrm{TiO}_{2}$ catalysts 

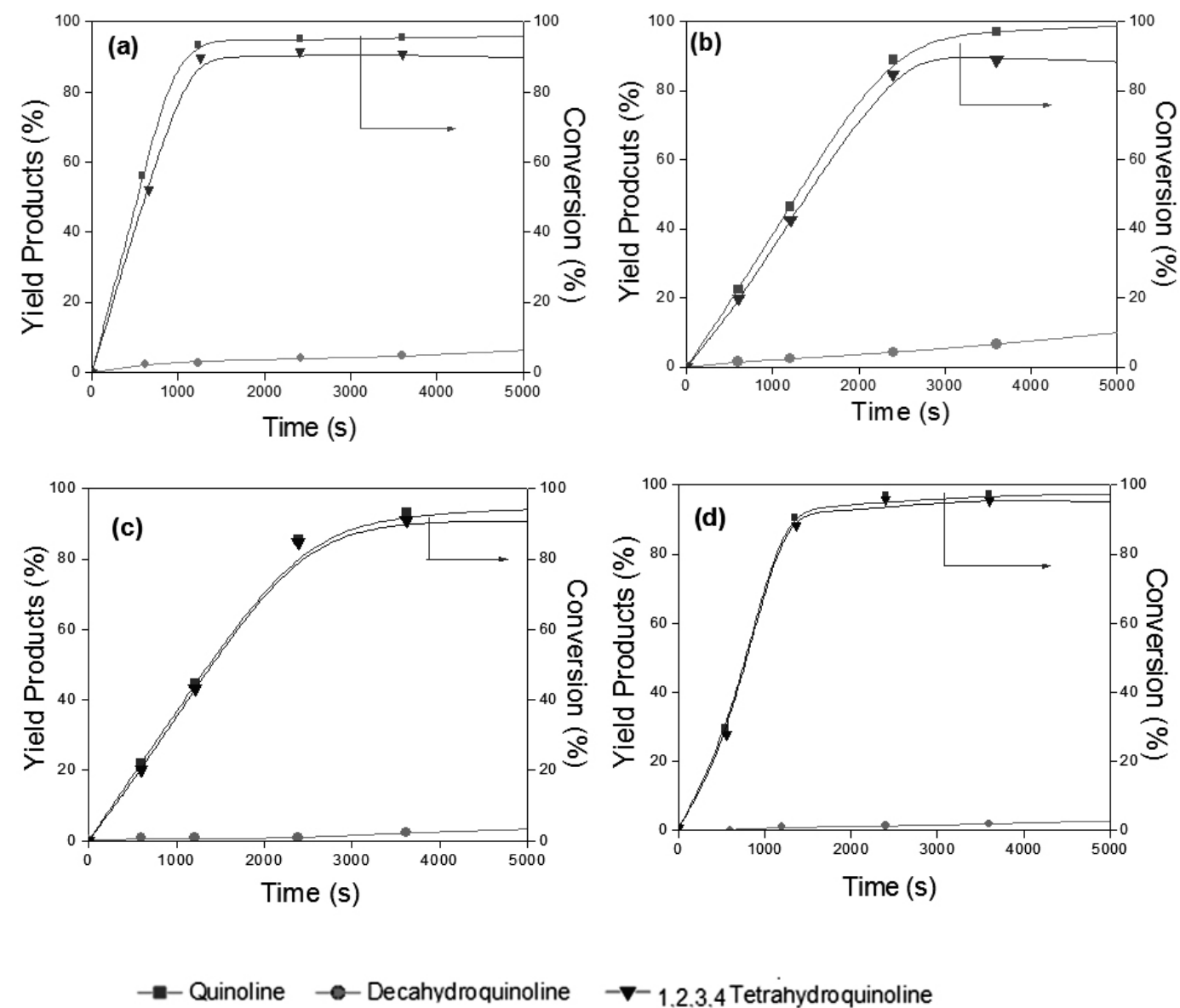

\subsubsection{Tetrahydroquinoline}

Figure 4: Quinoline conversion and yield of products over a) $\mathrm{Re} / \mathrm{SiO}_{2}$, b) $\mathrm{Re} / \gamma-\mathrm{Al}_{2} \mathrm{O}_{3}, \mathrm{c}$ ) $\mathrm{Re} / \mathrm{ZrO}_{2}$ and d) $\mathrm{Re} / \mathrm{TiO}_{2}$ catalysts.

Table 2 also shows that Re/M atomic ratios for the $\mathrm{ReS}_{2}$ /supports catalysts. This shows that $\mathrm{Re} / \mathrm{TiO}_{2}$ catalysts displayed the highest $\mathrm{Re} / \mathrm{M}$ atomic ratios, followed by $\mathrm{Re} / \mathrm{SiO}, \mathrm{Re} / \gamma-\mathrm{Al}_{2} \mathrm{O}_{3}$ and $\mathrm{Re} / \mathrm{ZrO}$ catalysts. This trend suggests that $\mathrm{ReS}$, was most highly dispersed on the $\mathrm{TiO}_{2}$ support, while it was poorly dispersed on the $\mathrm{ZrO}_{2}$ support, as previously observed by Laurenti et al. [14]. Unfortunately, HRTEM cannot be used to estimate the size of sulfide because the lamellar structure decomposes into spherical metallic particles under electron beam [14].

\subsection{Catalytic activity of catalysts}

Figure 4 illustrates the conversion of quinoline and yield of products over $\mathrm{ReS}_{2}$ /support catalysts as a function of time. It can be observed that the main reaction product was 1,2,3,4 tetrahydroquinoline (THQ1), and that decahydroquinoline (DHQ) was observed in minor amounts for all the catalysts. The conversion of quinoline by the $\operatorname{ReS}_{2}(\mathrm{x}) /$ supports catalyst can be depicted in the reaction scheme shown in Figure 5 , in agreement with previously reported studies by several authors $[4,5,6,9,10]$. Figure 5 shows that the formation of DHQ compound can be produced through hydrogenation of quinoline (either via THQ1 or THQ5 intermediate compounds). However, THQ5 was not detected under the experimental conditions used. Figure 6 illustrates the products distribution calculated at $40 \%$ of quinoline conversion.

The $\mathrm{Re} / \mathrm{SiO}$ and $\mathrm{Re} / \gamma-\mathrm{Al}_{2} \mathrm{O}_{3}$ catalysts displayed a higher yield to $\mathrm{DHQ}$ compound than the $\mathrm{Re} / \mathrm{ZrO}$ and $\mathrm{Re} / \mathrm{TiO}_{2}$ catalysts, suggesting that $\mathrm{SiO}_{2}$ and $\gamma-\mathrm{Al}_{2} \mathrm{O}_{3}$ supports slightly modified the active sites favouring the hydrogenation route. In this sense, Laurenti et al. [14] studied the HDS of thiophene over $\mathrm{Re} / \mathrm{ZrO}, \mathrm{Re} / \mathrm{TiO}_{2}$ and $\mathrm{Re} / \gamma-\mathrm{Al}_{2} \mathrm{O}_{3}$ catalysts, and suggested the formation of $\mathrm{ReS}_{(2-x)}$ under the reaction condition used. In other words, the authors proposed the formation of a metallic character in ReS. In fact, C. Sepulveda et al. [23] demonstrated by kinetic approach of competitive hydrogenation the presence of a metallic character on $\mathrm{ReS}_{2}$ supported on $\mathrm{SiO}_{2}$ and $\gamma-\mathrm{Al}_{2} \mathrm{O}_{3}$. Therefore, the higher yield to DHQ displayed by $\mathrm{Re} / \mathrm{SiO}_{2}$ and $\mathrm{Re} / \gamma-\mathrm{Al}_{2} \mathrm{O}_{3}$ catalysts could be attributed to higher $\operatorname{ReS}_{2}$ metallic character on these supports.

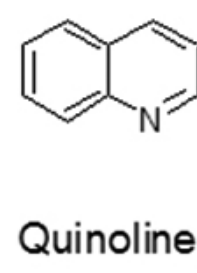<smiles>C1=CCCCC1</smiles><smiles>C=[Tl]</smiles>

THQ1<smiles>c1cnc2c(c1)CCCC2</smiles><smiles>C=CC</smiles><smiles>C1CCC2NCCCC2C1</smiles>

\section{THQ5}

\section{$\mathrm{DHQ}$}




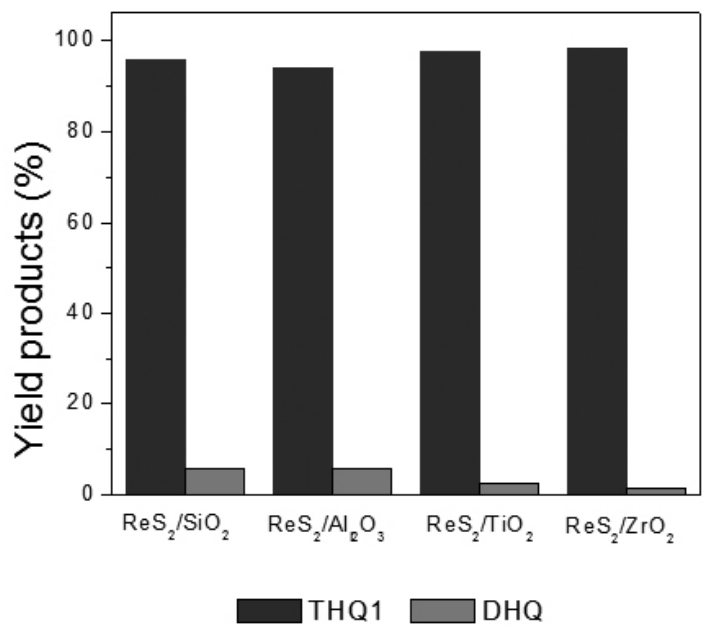

Figure 6: Products distribution at $40 \%$ conversion of quinoline for $\operatorname{ReS}_{2}(\mathrm{x}) /$ supports catalysts.
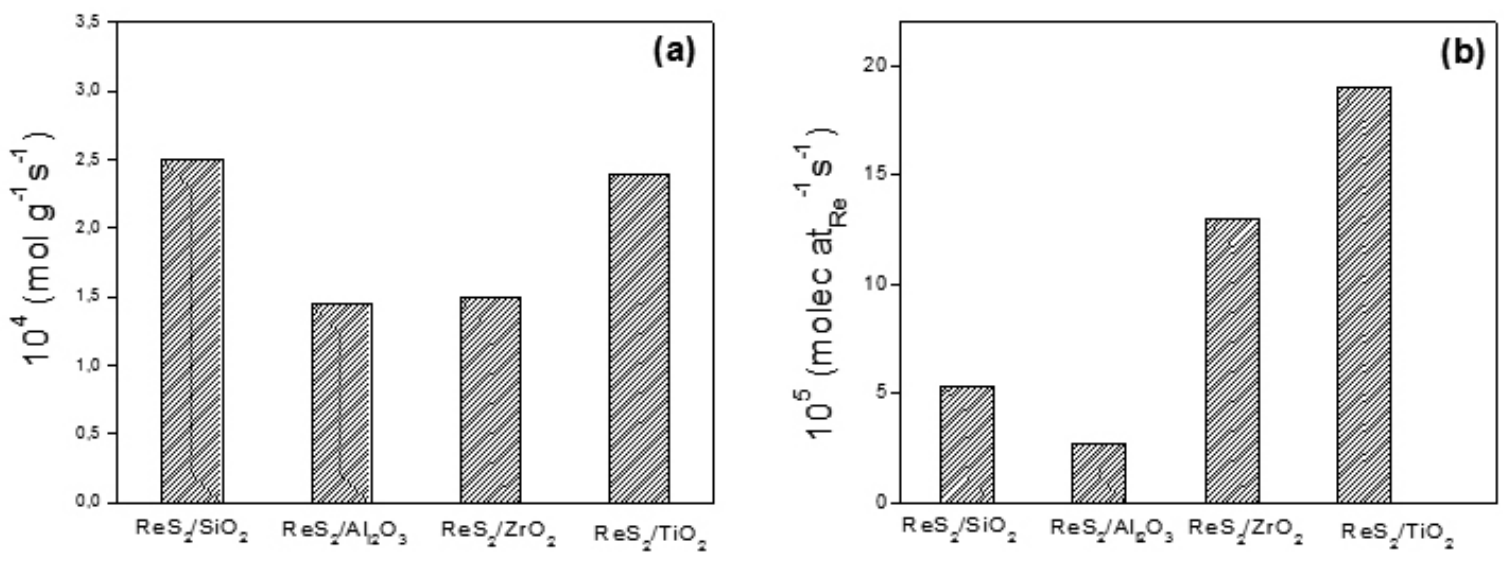

Figure 7: a) Specific rate and b) intrinsic rate of $\operatorname{ReS}_{2}(\mathrm{x}) /$ supports catalysts.

The negligible formation of $\mathrm{N}$-free compounds observed for the Re/support catalysts contrasts with the results reported recently by Fagar et al. [24] in the HDN of quinoline over $\mathrm{MoS}_{2}$ catalyst. The $\mathrm{MoS}_{2}$ displayed high selectivity to THQ1 and C9 products. This behaviour can be due to an inhibitive effect similar to those observed in the HDN of indole [25] and carbazol [26]. Laredo et al. [25] studied, by kinetic approach mechanism, the inhibition of indole and o-ethylaniline in the HDS of difenzothiophene (DBT) over commercial $\mathrm{Co}-\mathrm{Mo} / \gamma-\mathrm{Al}_{2} \mathrm{O}_{3}$ catalyst at conditions commonly used in the hydrotreatment of diesel feedstock. They observed an unexpected self-inhibiting effect of indole and o-ethylaniline in their hydrogenation process during DBT HDS. Similar self-inhibitive effect was observed in the HDN of carbazol and the HDS of DBT over Ni-MoP $/ \gamma-\mathrm{Al}_{2} \mathrm{O}_{3}$ commercial catalyst [26]. These results suggest a possible retardation in the formation of $\mathrm{N}$-free compounds in the batch reactor. In fact, reaction of these same catalysts in continuous flow reactor (elimination of self-inhibiting effect) showed high formation of $\mathrm{N}$-free compounds (data not show here).

Figure 7 shows the activity expressed as the initial rate (per gram of catalysts) and intrinsic initial rate (by metal atom) of all the catalysts evaluated in this study. Fig. 7a shows that the $\mathrm{Re} / \mathrm{SiO}_{2}$ catalyst displayed the highest initial rate followed by $\mathrm{Re} / \mathrm{Al}_{2} \mathrm{O}_{3}, \mathrm{Re} / \mathrm{ZrO}_{2}$ and $\mathrm{Re} / \mathrm{TiO}$ catalysts. This behaviour can be a function of Re atoms surface loading due to differences in the surface area of supports. Regarding the intrinsic activity, Fig. 7b shows that the $\mathrm{ReS}_{2} / \mathrm{TiO}_{2}$ catalyst displayed the highest intrinsic activity, followed by $\mathrm{Re} / \mathrm{ZrO}, \mathrm{Re} / \mathrm{SiO}_{2}$ and $\mathrm{Re} / \gamma-\mathrm{Al}_{2} \mathrm{O}_{3}$ catalysts. Similar trend was observed previously by Laurenti et $a l$. [14] in the conversion of thiophene. The highest intrinsic activity observed over the $\mathrm{Re} / \mathrm{TiO}_{2}$ catalyst can be attributed to higher ReS ${ }_{2}$ dispersion on the
$\mathrm{TiO}_{2}$ support, as suggested by XPS. On the contrary, the lower intrinsic activity displayed by $\mathrm{Re} / \gamma-\mathrm{Al}_{2} \mathrm{O}_{3}$ catalysts cannot be correlated with XPS results. This catalyst presented a similar $\mathrm{ReS}$, dispersion to the $\mathrm{Re} / \mathrm{ZrO}_{2}$ catalyst; however, the $\mathrm{Re} / \mathrm{ZrO}_{2}$ catalyst displayed an intrinsic activity about 4.5 times higher than the $\mathrm{Re} / \gamma-\mathrm{Al}_{2} \mathrm{O}$ catalyst. These results did not show a clear correlation between the catalytic activity and the structure of the $\gamma-\mathrm{Al}_{2} \mathrm{O}_{3}-, \mathrm{ZrO}_{2}$ - and $\mathrm{SiO}_{2}$-supported $\mathrm{ReS}_{2}$ catalysts, suggesting that other factors are involved in the conversion of quinoline, such as the existence of an electronic effect induced on the active phase by the support. Laurenti et al. [14] and Sepulveda et al. [23] reported the formation of $\mathrm{ReS}_{(2-x)}$ species under reaction condition over $\mathrm{SiO}_{2}, \gamma-\mathrm{Al}_{2} \mathrm{O}_{3}$ and $\mathrm{ZrO}_{2}-$, while over $\mathrm{TiO}_{2}$ catalyst apparently this specie was not formed. Therefore, the formation of $\mathrm{ReS}_{(2-x)}$ over $\gamma-\mathrm{Al}_{2} \mathrm{O}_{3}, \mathrm{ZrO}_{2}$ and $\mathrm{SiO}_{2}$ supports could favor the HYD pathway but decrease the quinoline conversion. This behavior contrasts results previously observed for the conversion of thiophene, suggesting that this species disfavor the adsorption of quinoline over the active site. However, in the case of $\mathrm{ZrO}$, support the intrinsic rate was higher than $\mathrm{Re} /$ $\mathrm{SiO}_{2}$ and $\mathrm{Re} / \gamma-\mathrm{Al}_{2} \mathrm{O}_{3}$ catalysts, this behavior is not clear. Future research should be aimed at clarifying this possible electronic effect (exact $\mathrm{ReOx}$ nature) versus Re dispersion on the HDN reaction over this active phase.

\section{CONCLUSIONS}

The $\operatorname{ReS}_{2}(1.5) /$ supported catalysts are highly active in the conversion of quinoline but exhibit negligible activity on the formation of N-compounds in a batch reactor. This behavior was attributed mainly to a self-inhibitive effect by some of the products from quinoline conversion in the batch reactor. 
The highest activity presented by the $\mathrm{ReS}_{2} / \mathrm{TiO}_{2}$ catalyst was attributed to the combined effect of Re dispersion and the formation of $\mathrm{ReS}_{2}$ species. Meanwhile, the activity trends displayed over the Re/ $\gamma-\mathrm{Al}_{2} \mathrm{O}_{3}, \mathrm{Re} / \mathrm{SiO}_{2}$ and $\mathrm{Re} / \mathrm{ZrO}_{2}$ catalysts cannot be related to any structural and textural properties of the catalysts, suggesting that the support can be involved in modifying the active site by electronic effect. The $\mathrm{Re} / \mathrm{SiO}$ and $\mathrm{Re} / \gamma-\mathrm{Al}_{2} \mathrm{O}_{3}$ catalysts displayed a higher yield to DHQ compound than the $\mathrm{Re} / \mathrm{ZrO}_{2}$ and $\mathrm{Re} / \mathrm{TiO}{ }_{2}$ catalysts. The results were attributed to higher $\mathrm{ReS}_{2}$ metallic character over $\mathrm{Re} / \mathrm{SiO}_{2}$ and $\mathrm{Re} / \gamma-\mathrm{Al}_{2} \mathrm{O}_{3}$ catalysts favouring of yield to DHQ compound but decreasing the quinoline conversion.

\section{ACKNOWLEDGMENTS}

The authors thank CONICYT-Chile for FONDECYT No 1130749 grant

\section{REFERENCE}

1.- $\quad$ Liu C, Yu Y, Zhao H, Fuel Processing Technology 25, 449 (2005)

2.- Fang M, Tang W, Yu C, Xia L, Xia Z, Wang Q, Luo Z, Fuel Processing Technology 129, 236 (2015).

3.- Ho T. C., Catal. Rev. Csi. Eng 30, 117 (1988).

4.- Deepa G, Sankaranarayanan T.M, Shanthi K, Viswanathan B., Catal. Today 198, 252 (2012).

5.- Yang S.H and Satterfield C.N., Ind. Eng. Chem. Process Des. Dev. 23, 20 (1984).

6.- Moreau C, Bekakra L, Durand R and Geneste P., Catal. Today 10, 681 (1991).

7.- Laredo G.C, Altamirano E, De los Reyes J.A. Appl. Catal A: Gen. 243, 207 (2013).

8.- Kabe T, Ishihara A, Qian W (1999) Hydrodesulfurization and Hydrodenitrogenation, in: Chemistry and Engineering, Wiley-VCHVerlag and Kodansa, Tokyo.

9.- Chouzier S, Vrinat M, T Cseri, Roy-Auberger M, Afanasiev P. Appl. Catal A:Gen 400, 82 (2011).
10.- Eijsbouts S, De Beer V.H.J, Prins R., J. Catal 127, 619 (1991).

11.- Escalona N, Vrinat M, Laurenti D, Gil Llambías F. J., Appl. Catal. A:Gen 322, 113 (2007).

12.- Escalona N, Ojeda J, Cid R, Alvez G, López Agudo A, Fierro J.L.G, GilLlambías F.J. Appl. Catal. A:Gen 232, 45 (2002)

13.- Escalona N, Ojeda J, Yates M, Lopez Agudo A, Fierro J.L.G and GilLlambías F. J. Applied. Catal. A:Gen 240,151 (2003).

14.- Laurenti D, Thoa K.T, Escalona N, Massin L, Vrinat M, Gil Llambías F. J. Catal Today 130, 50 (2008).

15.- Cáceres C.V, Fierro J.L.G, Lázaro J, López Agudo A, Soria J., J. Catal. 122, $113(1990)$

16.- Hédoire C.-E, Louis C, Davidson A, Breysse M, Maugé F, Vrinat M., J. Catal. 220, 433 (2003).

17.- Breysse M, Afanasiev P, Geantet C, Vrinat M., Catal. Today 86, 5 (2003)

18.- Laurenti D, Phung-Ngoc B, Roukoss C, Devers E, Marchand K, Massin L, Lemaitre L, Legens C, Quoineaud A.-A, Vrinat M., J. Catal. 297, 165 (2013).

19.- Brunauer S, Deming L, Deming W. E, Teller E. J. Am. Chem. Soc. 62, $1723(1940)$.

20.- Arnoldy P, Van Oers E. M, Bruinsma O. S. L, De Beer V. H. J, Moulijn J. A. Journal of Catalysis 93, 231 (1985).

21.- Leiva K, Martinez N, Sepulveda C, García R, Jiménez C. A, Laurenti D, Vrinat M, Geantet C, Fierro J. L. G, Ghampson I. T, Escalona N., Appl. Catal A:Gen 490,71 (2015)

22.- Leiva K, Sepulveda C, Garcia R, García J. L, Escalona N., Catal. Comm 53, 44 (2014).

23.- Sepulveda C, García R, Escalona N, Laurenti D, Massin L, Vrinat M, Catal Lett 141, 987 (2011).

24.- Farag H, Kishida M, Al-Megren H, Applied Catalysis A: Gen 469, 173 (2014).

25.- Laredo G.C, Altamirano E, De los Reyes J.A, Applied Catalysis A: Gen 242, 311 (2003).

26.- Laredo G. C, Montesinos A, De los Reyes J. A, Applied Catalysis A: Gen 265,171 (2004). 